\title{
Elementary School Teachers' Problems in Online Learning during the Pandemic
}

\section{Gusti Ayu Putu Sintha Arma Erawati ${ }^{*}$, I Wayan Widiana'2, I Gusti Ngurah Japa ${ }^{3}$}

\author{
1,2,3 Program Studi Pendidikan Guru Sekolah Dasar, Universitas Pendidikan Ganesha, Singaraja, Indonesia
}

\section{ART ICLE INF O}

\section{Article history:}

Received September 09, 2021

Revised September 12, 2021

Accepted October 20, 2021

Available online November 25, 2021

\section{Kata Kunci:}

Model Pembelajaran, Trikaya

Parisudha, Higher Order Thinking

Skills

\section{Keywords:}

Learning Model, Trikaya Parisudha, Higher Order Thinking Skills

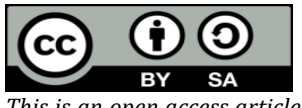

This is an open access article under the $C C$ BY-SA license.

Copyright (C) 2021 by Author. Published by Universitas Pendidikan Ganesha.

\begin{abstract}
A B S T R A K
Pandemi COVID-19 berimplikasi dalam berbagai bidang seperti bidang ekonomi, sosial, pariwisata, perdagangan, dan sebagainya. Salah satu bidang yang terdampak dari pandemi ini adalah pada bidang pendidikan. Pemerintah mewajibkan seluruh sekolah di Indonesia untuk melaksanakan kegiatan pembelajaran daring dari rumah. Kebijakan ini tentu menimbulkan berbagai macam masalah tidak hanya pada siswa saja, gurupun mengalami masalah ketika pembelajaran daring dilaksanakan. Penelitian ini dilaksanakan untuk menyimpulkan berbagai macam problematika yang dialami guru sekolah dasar dalam pembelajaran daring dimasa pendemi. Metode penelitian yang dilaksanakan peneliti adalah penelitian deskriptif, dengan populasi sebanyak 25.524 dengan sampel sebanyak 994 orang guru. Metode pegumpulan data menggunakan metode angket Skala Guttman. Data yang terkumpul dianalisis dengan metode deskriptif kuantitatif. Hasil penelitian menunjukkan bahwa guru-guru mengalami kendala pada semua dimensi. Yaitu pada dimensi komunikasi 65\%, dimensi metode pembelajaran 52\%, dimensi penilaian $61 \%$, dimensi penggunaan teknologi $43 \%$, dimensi jaringan sebesar 52\%, dimensi biaya pulsa/kuota 52\%, serta masalah dalam pembelajaran daring $74 \%$. Sehingga dapat disimpulkan bahwa guru sekolah dasar mengalami masalah pada semua dimensi yaitu pada dimensi komunikasi, dimensi metode pembelajaran, dimensi penilaian, dimensi penggunaan teknologi, dimensi jaringan, dimensi biaya pulsa/kuota, serta dimensi masalah dalam pembelajaran daring.
\end{abstract}

A B S T R A C T

COVID-19 pandemic has caused chaos in various field such as economic, social, tourism and many more. One of the fields that affected to it is in the field of education. The government requires schools in Indonesia to carry out online learning activities from home. This policy certainly raises various problems not only for students but also for teacher, many teachers faced problems during the online learning. This research was conducted to find out the problems experienced by elementary school teachers in online learning during the pandemic. The method of research carried out by the researchers is descriptive research, with a population of 25,524 elementary school teachers in Bali, and the research samples were taken from 994 teachers. The data collection method used is the Guttman Scale questionnaire with quantitative descriptive analysis method. The result of the research shows that teachers experience problems in all dimensions, such as the communication dimension with $65 \%$, the learning method dimension $52 \%$, the assessment dimension $61 \%$, the technology use dimension $43 \%$, the network dimension $52 \%$, the dimensions of the cost of cellular internet data $52 \%$ and problems in online learning in $74 \%$. It can be concluded that elementary school teachers faced the problems in all of dimentions such as communication dimension, the learning method dimension, the assessment dimension, the technology use dimension, the network dimension, the dimensions of the cost of cellular internet data also problems in online learning.

\section{INTRODUCTION}

On March 2020, WHO announced about the matter of COVID-19 pandemic around the world (Yuzulia, 2021a). Health experts from China stated that COVID-19 attacks the human respiratory organs. Pandemic of COVID-19 has spread rapidly throughout the world. WHO has announced that as many as 213 countries have been infected with COVID-19, including Indonesia, which made the government in Indonesia started to implement the program of PSBB or Large-Scale Social Restrictions in a number of areas that affected by COVID-19 (Dhawan, 2020; Mustakim, 2020; Realistis, 2020). This pandemic not only disrupted the economic aspect but various other aspects such as, social, tourism and also the education system in Indonesia (Putra, 2021; Rosali, 2020; Udayani et al., 2021). The COVID-19 pandemic has created major challenges for education worldwide (Weldon et al., 2021; Yuzulia, 2021b). Many schools are closed to avoid individual-to-individual interaction, which made teaching and learning activities must be shifted to online teaching and assessment (Hill et al., 2021; Usher et al., 2021). During time in this pandemic, the part of 
information and communication technology plays a major role in education (Logan et al., 2021; Tiwery et al., 2021). Online learning is a learning activity carried out remotely using the internet network from home or any place as long as the network is working. Online learning can be said as a learning that is carried out remotely through media with the help of internet and other supporting tools as its media such as cell phones and computers (Christianto, 2020; Putria, Maula, \& Uswatun, 2020; Yulia, 2020). In addition, another researchers also concluded that online learning is learning that uses the internet network with accessibility, connectivity, flexibility, and the ability to bring up various types of learning interactions (Astini, 2020; Handarini \& Wulandari, 2020; Sadikin \& Hamidah, 2020).

In Indonesia, there are still quite a lot of people who do not have proper facilities and infrastructure to use online learning, this is one of the condition that is quite difficult for the education community. Not all parents of students have devices that can help to facilitate online learning such as laptops and cellphones, and from these conditions, parents experience problems related to the costs and use of technology (Agustin et al., 2020; Arizona et al., 2020). During pandemic, parents also get the additional task of being a teacher, because parents have to guide their children when online learning is carried out (Mastura \& Santaria, 2020; Slovaček \& Čosić, 2020). In addition to this condition, many problems will also arise when online learning is carried out such as the ineffective way of technology in learning, the use of credit fees and internet data is also increased (Handayani et al., 2020; Purwanto et al., 2020; Roni Hamdani \& Priatna, 2020). Beside of that, the policy of learning from home certainly raises many other problems such as student learning activities, interference in assessment, cancellation of assessments, opportunities to get a job after completing education, as well as cancellation of public assessments for qualifications in job selection (Aji, 2020; Dewi, 2020; Hamid et al., 2020). Problems during the online learning are not only experienced by students, teachers also experience problems when preparing or providing online learning to students. Some teachers even have low competence related to online learning (Hutauruk \& Sidabutar, 2020; Malyana, 2020). In addition to students and teachers who have difficulty when online learning is implemented, parents also experience difficulties because parents get extra work, which is accompanying children during the online learning (Kurniati et al., 2020; Satrianingrum \& Prasetyo, 2020). Therefore, this research was carried out to find out what problems were experienced by elementary school teachers in online learning during the pandemic.

Based on the results of observations made by researchers before the research was carried out, it was known that when online learning was implemented, teachers still had problems using learning tools, internet networks and devices, learning management, assessment, and supervision (Hutauruk \& Sidabutar, 2020; Rigianti, 2020). Similar research was already carried out, in that research, it was found that the obstacles experienced by preschool teachers during the COVID-19 pandemic can be classified in four indicators, which are communication barriers, learning methods, materials also costs and the use of technology (Agustin et al., 2020; Indrawati et al., 2020). Another obstacle experienced was come from students where not all of students have cellphones. Hence students have to carry out online learning using their parents' mobile phones (Putria, Maula, \& Uswatun. D. A., 2020; Susilowati \& Azzasyofia, 2020). The lack of knowledge about the use of application technology during the online learning and large expenses are obstacles for teachers when the online learning process takes place (Hanifah Salsabila et al., 2020; Mastura \& Santaria, 2020). If the problems presented by some of the researchers above are ignored, it absolutely will have an impact on the quality of education in Indonesia.

The solution offered in some research is related to most of the problems experienced when online learning is implemented, which is teachers should improve communication with students and students' parents. Therefore parents can help children in learning (Indrawati et al., 2020; Mastura \& Santaria, 2020). The solution related to network problems experienced by students is by suggesting students to watch the learning activity portal provided by the Ministry of Education and Culture through television broadcasts (Rigianti, 2020). Teachers must also be able to apply varied methods threupon learning activities become interesting and fun. A teacher must at least be able to combine targeted and appropriate learning methods and media (Akhwani \& Romdloni, 2021; Malyana, 2020; Wuarlela, 2020). Teachers' skills in using technology tools must be improved more in order to be able to design appropriate and suitable methods and determined a great media so that they can be used in online learning (Abidah et al., 2020; Mastura \& Santaria, 2020). Technology and information can help to convey lessons or knowledge to students in schools so that teaching activities can run effectively (Chang et al., 2020; Simanjuntak et al., 2020; Teräs et al., 2020). Previous research findings also state that technology can be used in the learning process to make learning flexible (Bakri et al., 2016; Herdiana et al., 2021; Sindiani et al., 2020). However, the solutions provided refer more to the problems faced by students when carrying out online learning from home. From this research, no one has provided a solution related to the problems experienced by teachers when carrying out online learning. The difference between this study and other research is that this study will describe in more detail the various problems or obstacle experienced by elementary school teachers in online learning during the 
pandemic. The government is also expected to do more review related to teacher training on several matters related to online learning. In the training, at least the teachers can be taught about some applications that can be used in online learning applications. As well as training on how to use these applications until teachers master how to use these applications. Hence, if the online learning period is carried out again, there will be no similar problems that will occur. Based on some of the problems described above, this study was conducted to find out what problems were experienced by elementary school teachers in online learning during the pandemic, especially in the province of Bali.

\section{METHOD}

This research's type is descriptive research and the method of this research is descriptive research. Descriptive research focuses on solving actual problems at the time the research was carried out, this is in accordance with the objectives of this study. Where this study aims to find out the problems that researchers found, where researchers would look for data related to the problems faced by elementary school teachers in online learning during the pandemic, especially in Bali Province. The population is a generalization area consist of; objects/subjects that have certain qualities and characteristics determined by researchers to be studied and then to be drawn as a conclusions (Sugiyono, 2012). Hence, based on the opinions of several experts above, it can be concluded that the population is the entire object in a study which is sum based on the quantitative and qualitative values of an object/subject completely and clearly to be studied and then drawn conclusions. In this study, the population was taken from three regencies, which are Denpasar City, Buleleng Regency, and Bangli Regency. The 3 districts will be further subdivided based on urban, suburban and village areas. Then going through, the sample is part of the population taken, which is considered representative of the entire population and is taken using certain techniques (Agung, 2014). Another addition is about the sample as part of the number and characteristics possessed by the population (Sugiyono, 2015). So it can be concluded that the sample is part of the population taken using certain techniques to determine the number and characteristics possessed by a population. Researchers will have difficulty in studying everything in the population if the population is present in large numbers. Therefore, in a study, researchers can use samples taken from a population.

The sampling technique in this study consisted of two sampling techniques, namely, Probability Sampling and Non-Probability Sampling. Probability Sampling includes: Cluster Random Sampling, Simple Random Sampling, and Stratified Random Sampling. Meanwhile, Nonprobability Sampling is Accidental Sampling. Cluster Sampling is sampling on the basis of clusters/groups, because in cluster sampling, each sub-group consists of a heterogeneous population. This technique is used if the population does not consist of individuals, but consists of groups of individuals or clusters, if the cluster is selected, all members in the cluster become the sample (Retnawati, 2017). Cluster Random Sampling was carried out by grouping teachers into 9 groups based on districts. Simple Random Sampling is a research sampling technique with simple random sampling. Based on the grouping of 9 districts, the research sample will be taken using the Simple Random Sampling technique. Three regencies that will be selected as sampling sites, namely Denpasar City, Buleleng Regency and Bangli Regency will be taken as research samples. Stratified Random Sampling is a technique of grouping population members based on their strata. Accidental Sampling is a sampling technique by taking anyone who happens to meet with the researcher and according to the researcher is suitable as a research sample, to be used as a sample. The researcher used the Accidental Sampling technique to collect data from primary schools in the three districts selected as research samples. The data collection method used in this study is a non-test method, where data collection is carried out using a questionnaire method. This questionnaire method was one of the methods of collecting data by obtaining or collecting data by sending a list of questions/statements related to the things they want to know through research conducted to research respondents. The questions used are closed questions, which is questions in the form where respondents will only choose the answers available in the questionnaire that has been prepared by the researcher. Questions will be prepared in the form of a Google Form by the researcher.

Table 1 Blueprint of Teacher Response Questionnaire

\begin{tabular}{|c|c|c|c|c|c|}
\hline \multirow{2}{*}{ No. } & \multirow{2}{*}{ Dimention } & \multirow{2}{*}{ Indicator } & Statement & \multirow{2}{*}{\multicolumn{2}{|c|}{$\begin{array}{c}\text { Number of } \\
\text { Item }\end{array}$}} \\
\hline & & & + & & \\
\hline & Comunication & a. Communication wih students' parents & $\sqrt{ }$ & 1 & 12 \\
\hline & & b. Interaction with students & $\sqrt{ }$ & & $313,15,17$ \\
\hline & & $\begin{array}{l}\text { c. Parents that do not have proper communication } \\
\text { tools }\end{array}$ & $\sqrt{ }$ & 1 & 19 \\
\hline & & d. Parents that are busy and cannot be contacted & $\sqrt{ }$ & 1 & 20 \\
\hline
\end{tabular}




\begin{tabular}{|c|c|c|c|c|c|}
\hline \multirow{2}{*}{ No. } & \multirow{2}{*}{ Dimention } & \multirow{2}{*}{ Indicator } & Statement & \multirow{2}{*}{ Total } & \multirow{2}{*}{$\begin{array}{c}\text { Number of } \\
\text { Item }\end{array}$} \\
\hline & & & + & & \\
\hline \multirow[t]{3}{*}{2} & Learning & a. The use of learning method during online learning & $\sqrt{ }$ & 1 & 18 \\
\hline & Method & $\begin{array}{l}\text { b. The plan making of the use of learning device that } \\
\text { customized with online learning system }\end{array}$ & $\sqrt{ }$ & 1 & 10 \\
\hline & & $\begin{array}{l}\text { c. Learning media that can be used during online } \\
\text { learning }\end{array}$ & $\sqrt{ }$ & 1 & 7 \\
\hline 3 & Assesment & a. Student assesement & $\sqrt{ }$ & 3 & $9,14,16$ \\
\hline \multirow[t]{2}{*}{4} & The use of & a. The use of application during online learning & $\sqrt{ }$ & 1 & 4 \\
\hline & Technology & b. The use of facilitation during online learning & $\sqrt{ }$ & 2 & 3,12 \\
\hline \multirow{2}{*}{$\begin{array}{l}5 \\
6\end{array}$} & Network & a. Internet quality during online learning & $\sqrt{ }$ & 1 & 5 \\
\hline & $\begin{array}{l}\text { Internet Data } \\
\text { Fee }\end{array}$ & a. Cellular data fees during the online learning & $\sqrt{ }$ & 1 & 8 \\
\hline \multirow[t]{3}{*}{7} & Problem & a. Problem during online learning & $\sqrt{ }$ & 1 & 2 \\
\hline & during online & b. Teaching experiences during online learning & $\sqrt{ }$ & 1 & 1 \\
\hline & learning & c. Problem during presenting the material to students & $\sqrt{ }$ & 1 & 6 \\
\hline
\end{tabular}

The data analysis method used in this research is descriptive quantitative. Quantitative research is related to data that can be measured quantitatively, using the symbols of numbers (Subandi, 2011). Quantitative analysis is a method used to answer research problems related to data in the form of numbers and statistical programs. This will be used when the researcher will describe the results of the questionnaire that will be used to collect data for elementary school teachers. In the questionnaire that will be used to carry out research, quite a number of aspects are reviewed so that this research is expected to produce a complex analysis. In this study, the analysis used was descriptive analysis of the Guttman scale with percentage statistical techniques. The Guttman scale will provide a firm response, which consists of two alternatives, namely "Yes" and "No".

\section{RESULT AND DISCUSSION}

\section{Result}

Based on the research that has been carried out by the researcher, the researcher would be displayed the results of the data that has been collected from the google form according to the dimensions and the area where the data collection is carried out in the form of the following table.

Table 2 Results of Recapitulation from 3 Regions

\begin{tabular}{llcccccc}
\hline \multirow{2}{*}{ No } & & \multicolumn{2}{c}{ Cityention } & \multicolumn{2}{c}{ Suburbs } & \multicolumn{2}{c}{ Village } \\
\cline { 3 - 7 } & & Yes & No & Yes & No & Yes & No \\
\hline 1 & Comunication & $66 \%$ & $34 \%$ & $66 \%$ & $34 \%$ & $65 \%$ & $35 \%$ \\
2 & Learning Method & $57 \%$ & $43 \%$ & $53 \%$ & $47 \%$ & $45 \%$ & $55 \%$ \\
3 & Assesment & $61 \%$ & $39 \%$ & $62 \%$ & $38 \%$ & $60 \%$ & $40 \%$ \\
4 & The use of Technology & $40 \%$ & $60 \%$ & $48 \%$ & $52 \%$ & $40 \%$ & $60 \%$ \\
5 & Network & $50 \%$ & $50 \%$ & $55 \%$ & $45 \%$ & $51 \%$ & $49 \%$ \\
6 & Internet Data Fee & $52 \%$ & $48 \%$ & $54 \%$ & $46 \%$ & $51 \%$ & $49 \%$ \\
7 & Problem during online learning & $73 \%$ & $27 \%$ & $77 \%$ & $23 \%$ & $71 \%$ & $29 \%$ \\
\hline \multicolumn{2}{c}{ Total } & $\mathbf{5 7 \%}$ & $\mathbf{4 3 \%}$ & $\mathbf{5 9 \%}$ & $\mathbf{4 1 \%}$ & $\mathbf{5 5 \%}$ & $\mathbf{4 5 \%}$ \\
\hline
\end{tabular}

In general, the results of research that has been carried out by researchers, related to the problems faced by elementary school teachers in online learning in three areas, namely cities, suburbs and villages, . From the table, it can be seen that the total of persentage of highest problem occured during the online learning is on suburbs, it can be happened because suburbs are residents from various areas from village and city. So the problems experienced by teachers are quite diverse. Starting from communication problems, difficulties in determining the methods and media to be used when carrying out online learning, experiencing problems when conducting student assessments, unstable networks, experiencing problems regarding cellular data fees, and many others problems in online learning. In the communication dimension, the percentage of each region shows that, problems in urban areas (city) are $66 \%$, in suburban areas $66 \%$, while in rural areas (village) 65\%, lower than urban and suburban areas. This was because in rural areas teachers can perform communication activities with parents of students with the offline method so that it was not too hard for teachers to carry out communication with parents of students. However, in urban and 
suburban areas, of course, communication became a problem because the policy to implement health protocols in urban and suburban areas was and is very strict, so teachers also experienced problems when carrying out communication activities with students and parents. In the dimension of the learning method, the percentage of each region shows that the problem was in urban areas (city) 57\%, in suburban areas $53 \%$, while in rural areas (village) $45 \%$. Urban and suburban areas experienced the highest problems related to learning methods, this was because teachers were required to be creative in preparing interesting media and methods hence it can be used to carry out during online learning activities and they usually only adjust the design of learning devices that are adapted to online learning activities.

In the dimension of the percentage assessment of each region, it showed that the problem was in urban areas (city) 61\%, in suburban areas 62\%, while in rural areas (village) $60 \%$. Of course, all schools in the three regions experienced problems related to the assessment this was due to the difficulty of teachers to take real grades from students, because as we know at this time teachers could not monitor student activities directly so that teachers also had problems carried out assessments of students. In the dimension of technology use, the percentage of each region showed that the problem was in urban areas (city) 40\%, in suburban areas 48\%, while in rural areas (village) $40 \%$. The percentages of the three regions got a fairly low percentage, this was because the three regions did not have too many problems related to the use of applications and the use of facilities and infrastructure used when carrying out online learning, so it can be said that quite a lot of teachers have mastered the use of applications and also the use of facilities and infrastructure. used when carrying out online learning. However, from this percentage it also meant that there were some teachers who were still experiencing problems related to the use of applications and also the use of facilities and infrastructure used in the implementation of online learning, this was usually influenced by the lack of teacher skills in using the facilities and infrastructure used in carrying out online learning, and the lack of ability in the use of applications used in carrying out online learning. In the dimension of technology use, many teachers experienced ignorance regarding applications that can be used to carry out online learning. Actually applications that can be used to carry out online learning are Zoom Meeting, Google Meet, Google Classroom and Google Form. Meanwhile, not too many teachers have the experience to use the applications used to conduct online learning. Because most teachers use the WhatsApp application when carrying out online learning.

In the dimension of the network, the percentage of each region shows that the problem was in the urban area (city) 50\%, in the suburban area 55\%, while in the rural area (village) 51\%. The three experienced the same percentage, this was due to the various topographic conditions of each region, so that some experienced problems and some did not. However, especially in rural areas (village), most teachers use the offline method so that teachers who were especially in rural areas fel that they did not experience network problems. In the dimensions of the cellular data fee percentage from each region, it showed that the problem was in urban areas (city) 52\%, in suburban areas 54\%, while in rural areas (village) 51\%. This happened because most teachers still used their personal internet data to carry out online learning. On the celulaar data fee dimension, many teachers complained about the amount of internet daata that they spent when carrying out online learning, because most of these teachers use the WhatsApp and YouTube applications when carrying out online learning. Meanwhile the internet data that they got from the goverment did not cover the application aside of chat application and conference application, hence the internet data of assistance from the government cannot be used to carry out online learning, according to the teachers. In the problem dimension in online learning, the percentage of each region showed that the problem was in urban areas (city) 73\%, in suburban areas 77\%, while in rural areas (village) $71 \%$. From the previous dimensions, the problem dimension in online learning had the highest percentage, because it reached $70 \%$ and more. Before the obligation of online learning was carried out, there were also many teachers who had carried out online learning activities, but when online learning was carried out suddenly, many teachers were not ready and complained of the problems when it was implemented, whether it was from students or teachers.

In general, rural areas (village) experienced the fewest problems related to online learning. This was because mos of the village area combined online and offline learning activities. Most schools located in rural areas (village) carried out school activities offline and online (blended leaning), this was because the network was not very worked, especially in mountainous areas where in that area is hard to get any signal for cellphone and internet. So when filled out the google form link and the questionnaire response sheet, not many teachers chose to say they had problems because most schools in rural areas decided to combine online and offline learning simultaneously. Things that affected why offline learning activities were also carried out in some school in rural and suburban areas, were the lack of teacher skills in using the facilities and infrastructure used to carry out online learning, teachers in rural and suburban areas were mostly little bit old an almost approaching the age ofretiring, also most of them had no idea how to use technology in 
online learning. Hence these teachers had less skills in using the facilities and applications used to carry out online learning.

\section{Discussion}

In the communication dimension there were several questions related to communication problems with parents, interaction with students, parents who do not have proper and suitable communication tools, and parents who are difficult to contact due to busy work. Problems in the communication dimension with the largest percentage were happened in urban and suburban areas. This high percentage was because of the teachers which could not interact directly with students, because basically learning is an interaction between teachers and students (Agustin et al., 2020; Silwana et al., 2020; Thoyyibah et al., 2019). Using technology tends to eliminate social interaction between teachers and students (Blakely et al., 2020; Simanjuntak et al., 2020; Summak et al., 2010). Parents of students who did not have supporting devices and also busy parents who were busy working and caused the students cannot join the online learning process properly. Communication between teachers and schools with parents must be established smoothly for the success of learning (Dewi, 2020; Hartmann et al., 2021). Teachers must improve communication with students and parents, as well as some students who do not have the devices to carry out online learning, to contact their closest friends who have proper and suitable devices, to find out the tasks and materials provided by the teacher (Mastura \& Santaria, 2020; Rigianti, 2020).

Next is the dimension of learning methods. In the dimension of the learning method, there were several questions related to the problem of using the learning methods used when online learning was carried out, designing learning devices when online learning is carried out and the media used when carrying out online learning. In the dimensions of the learning method the largest percentage is in the city area. The problem experienced by teachers when carrying out online learning in the dimension of the learning method is of course the determination of the methods and media that will be used when online learning is carried out. Teachers are required to be even more creative in making media to present material and determining the methods to be used when carrying out online learning, so that when learning is carried out, the teacher can increase student learning motivation, so that the material that students learned can be grasphed correctly and appropriately. In addition, students also have different brain capacities (Antal et al., 2017; Mastura \& Santaria, 2020; Ryu et al., 2021). A teacher must be able to apply a variety of methods so that learning activities become interesting and fun, by involving parents in providing material and using learning methods that are suitable for children's development (Agustin et al., 2020; Garad et al., 2021; Soucy et al., 2016). Teachers can also use digital game-based learning innovations, this has received good attention in the world of education (All et al., 2021; Hung et al., 2014; Xie et al., 2021). Teachers also experience problems in redesigning learning devices, because teachers usually design learning tools with makeshift media (Adlin, 2019; Kao, 2020). So teachers have to adapt to current conditions that is happening around them.

In the assessment dimension, there were several questions related to the assessment carried out on students. In the assessment dimension, the area experiencing problems with the largest percentage was the suburbs. Difficulty to give assessment was one of the problems experienced by teachers when carrying out online learning. Because the assessment was not only an assessment of learning outcomes, but also other assessments, such as assessment of attitudes and also assessment of homework. Teachers experience obstacles in cultivating an independent attitude and an interested of reading in students, this was one thing that teachers could not do, so teachers could not carry out attitude assessments towards students (Wang et al., 2018). Assessment occurs naturally when students interact, communicate, and socialize with friends and teachers (Hughes et al., 2019; Kaplan et al., 2021; Rigianti, 2020). The existence of online learning eliminates the socialization of students with other students directly. So that it became an obstacle for teachers in assessing students. Another problem faced by teachers was when teachers gave assignments to students, students did not fully do their own assignments, because most parents intervene when students do assignments given by the teacher (Chen et al., 2019; Puspitasari et al., 2021; Satrianingrum \& Prasetyo, 2020).

In the dimension of technology use, there were several questions related to the use of applications when carrying out online learning, as well as the use of facilities and infrastructure used when carrying out online learning. In the dimension of technology use, the areas experiencing problems with the largest percentage are the suburbs. Teachers who teached in elementary schools in suburban areas experienced problems related to the use of technology used to carry out online learning, this was because teachers in suburban areas only used mobile phones as a means of carrying out online learning with students. Teachers also mostly used whatsapp as an application used to contact and send assignments to students. However, with further explanation, WhatsApp is a social media application that is used to socialize between individuals and groups (M. Daheri et al., 2020; Mirzon Daheri et al., 2020; Trisnani, 2017). Teachers who 
experienced problems related to the use of technology and applications in carrying out online learning were caused by the lack of teacher skills in using facilities and infrastructure in online learning (Hong et al., 2021; Kim \& Gurvitch, 2020; Morze et al., 2021). However, teacher skills in using technology are still lacking, especially senior teachers who are still not proficient in using devices or facilities to support the implementation of online learning (Dewi, 2020). Before online learning is carried out, it is better for teachers to carry out training related to online learning (Heng \& Sol, 2020; Mastura \& Santaria, 2020; Meșe \& Sevilen, 2021). In the network dimension there were questions related to the quality of the internet network when carrying out online learning. In the network dimension, the area experiencing problems with the largest percentage is the suburbs. Networks play a very important role in supporting effective and fast communication in various forms of communication between parties (Hamaidi et al., 2021; Udayani et al., 2021). An unstable internet connection is one of the obstacles in the implementation of online learning (Rosali, 2020; Wu et al., 2019). That was the reason of many schools that chose to install wi-fi so that teachers could carry out online learning activities while they in school. Schools as educational institutions must be ready to facilitate any changes related to education, one example was providing wi-fi, hence teachers can be helped to do online learning (Aji, 2020; Gillett-Swan, 2017). A good solution related to network problems experienced by students was by suggesting students to watch the learning activity portal provided by the Ministry of Education and Culture through television broadcasts (Rigianti, 2020).

In the cellular data fee dimension, there were questions related to the cellular data fee used during online learning. In the cellular data fee dimension, the areas experiencing problems with the largest percentage are suburban areas. This was because there were still many teachers who used personal internet data when carrying out online learning with students. Many teachers complained that the internet data that they got from the government could only be used for certain applications such as Google Meet, Zoom Meeting, and Google Classroom. While most teachers in suburban carried out online learning through Whatsapp application. Money that they spent also did not only led to the purchase of internet data only but also to the communication costs with principals, and students' parents such as cellular data and other expenses, because the communication did by teachers must continue to run well so that teachers can monitor student progress in learning (Bdiwi et al., 2019; Mastura \& Santaria, 2020; Yulian, 2018). In addition to this statement, the implementation of online learning using video conferencing required quite expensive costs (Kim \& Gurvitch, 2020; Morze et al., 2021).

In the problem dimension in learning there were several questions related to problems when carried out online learning, teaching experiences with online methods and problems when presenting material to students. In the dimension of problems in online learning, the areas experiencing problems with the largest percentage are the suburbans. Problems that they experienced when carried out online learning were such as the problems described above. Based on the survey results, it was stated that teachers experience problems when carrying out online learning (Roni Hamdani \& Priatna, 2020; Saha et al., 2021). Some of the obstacles experienced by teachers during online learning were the limited mastery of information technology by teachers and students, inadequate facilities and infrastructure, limited internet access, and the unprepared budget thaat was needed when online learning was implemented (Lage-Cala et al., 2020; Rasidi et al., 2021). One of communication problems that occured are still many students who used their parents' cellphones so that they were quite difficult to follow the lesson because parents are busy working, difficulty in determining the media and methods to be used, carrying out assessments of students, as well as network quality problems and also the cost of internet data used to carry out online learning (Putria, Maula, \& Uswatun, 2020; Tan, 2021). In addition to this statement, the teacher also experienced problems when providing material to students. Because teachers were required to be more creative when providing material to students, either by making learning videos and so on. Related to these problems, it is hoped that the government can provide solutions, hence the problems experienced by elementary school teachers can be decreased properly, and that learning activities in elementary schools did not experience problems.

Each dimension in the questionnaire blueprint were used for data collection in the research field contained the problems experienced by teachers during online learning. After the researchers carried out the research, the researchers found that there were still many elementary school teachers who had problems when carrying out online learning so, the researchers hoped that this research could help elementary school teachers find the solutions related to the problems experienced by teachers when online learning was implemented. The limitation of the research carried out by the researcher is time, because the sample is huge and the researcher spent a lot of time to reach many schools that will be used as research samples, then the researchers implemented great time management in the research, so that researchers get the proper data t be collected and investigated. Based on the results of research data, the implications of the results of research that have been carried out by researchers are expected, so that teachers can master the use of facilities and infrastructure used in online learning and can increase creativity in order to determine 
methods and create interesting media to give to students. Hence, later students can get interesting and fun learning when online learning is carried out. In the future, the results of this study can also be used as a source or reference that will be used to find out the problems faced by teachers in online learning during the pandemic in Bali Province.

\section{CONCLUSION}

Based on the results of the research, it can be concluded that teachers experienced problems in the dimensions of communication, dimensions of learning methods, dimensions of assessment, dimensions of technology use, dimensions of networks, dimensions of cellular data fees, and problems in online learning.

\section{REFERENCES}

Abidah, A., Hidaayatullaah, H. N., Simamora, R. M., Fehabutar, D., \& Mutakinati, L. (2020). The Impact of Covid-19 to Indonesian Education and Its Relation to the Philosophy of "Merdeka Belajar." Studies in Philosophy of Science and Education, 1(1), 38-49. https://doi.org/10.46627/sipose.v1i1.9.

Adlin. (2019). Analisis Kemampuan Guru Dalam Memanfaatkan Media Bebasis Komputer Pada Pembelajaran Di Sekolah Dasar. Imajinasi: Jurnal Seni, 3(2), 30-35. https://doi.org/10.26858/i.v3i2.12961.

Agung, A. A. G. (2014). Metodologi Penelitian Pendidikan. Aditya Media Publish.

Agustin, M., Puspita, R. D., Nurinten, D., \& Nafiqoh, H. (2020). Tipikal Kendala Guru PAUD dalam Mengajar pada Masa Pandemi Covid 19 dan Implikasinya. Jurnal Obsesi : Jurnal Pendidikan Anak Usia Dini, 5(1), 334-345. https://doi.org/10.31004/obsesi.v5i1.598.

Aji, R. H. S. (2020). Dampak Covid-19 pada Pendidikan di Indonesia: Sekolah, Keterampilan, dan Proses Pembelajaran. SALAM: Jurnal Sosial Dan Budaya Syar-I, $7(5)$. https://doi.org/10.15408/sjsbs.v7i5.15314.

Akhwani, \& Romdloni, M. A. (2021). Indonesian Journal of Primary Education. Indonesian Journal of Primary Education, 5(1), 1-12. https://doi.org/10.17509/ijpe.v5i1.31381.

All, A., Castellar, E. N. P., \& Looy, J. Van. (2021). Digital Game-Based Learning effectiveness assessment: Reflections on study design. Computers \& Education, 167. https://doi.org/10.1016/j.compedu.2021.104160.

Antal, H., Bunnell, H. T., McCahan, S. M., Pennington, C., Wysocki, T., \& Blake, K. V. (2017). A cognitive approach for design of a multimedia informed consent video and website in pediatric research. Journal of Biomedical Informatics, 66, 248-258. https: //doi.org/10.1016/j.jbi.2017.01.011.

Arizona, K., Abidin, Z., \& Rumansyah, R. (2020). Pembelajaran Online Berbasis Proyek Salah Satu Solusi Kegiatan Belajar Mengajar Di Tengah Pandemi Covid-19. Jurnal Ilmiah Profesi Pendidikan, 5(1). https://doi.org/10.29303/jipp.v5i1.111.

Astini, N. K. S. (2020). Pemanfaatan Teknologi Informasi dalam Pembelajaran Tingkat Sekolah Dasar pada $\begin{array}{llll}\text { Masa Pandemi } \quad \text { Covid-19. } & \text { Lampuhyang, }\end{array}$ https://doi.org/10.47730/jurnallampuhyang.v11i2.194.

Bakri, F., Siahaan, B. Z., \& Permana, A. H. (2016). Rancangan Website Pembelajaran Terintegrasi dengan Modul Digital Fisika Menggunakan 3D PageFlip Professional. Jurnal Penelitian \& Pengembangan Pendidikan Fisika, 2(2), 113-118. https: //doi.org/10.21009/1.02215.

Bdiwi, R., de Runz, C., Faiz, S., \& Cherif, A. A. (2019). Smart learning environment: Teacher's role in assessing classroom attention. Research in Learning Technology, 27, 1-14. https://doi.org/10.25304/rlt.v27.2072.

Blakely, M. L., McKnight, K. D., Darling, R. A., \& Moody, E. J. (2020). Using an OSCE to assess the potential for assistive technology to enhance communication between student pharmacists and simulated patients who are deaf/hard of hearing. Journal of the American Pharmacists Association, 60(6). https: //doi.org/10.1016/j.japh.2020.08.031.

Chang, T. Y., Hong, G., Paganelli, C., Phantumvanit, P., Chang, W. J., Shieh, Y. S., \& Hsu, M. L. (2020). Innovation of dental education during COVID-19 pandemic. Journal of Dental Sciences, 155. https://doi.org/10.1016/j.jds.2020.07.011.

Chen, Y., Mayall, H. J., York, C. S., \& Smith, T. J. (2019). Parental perception and English Learners' mobileassisted language learning: An ethnographic case study from a technology-based Funds of Knowledge approach. Learning, Culture and Social Interaction, 22. https: //doi.org/10.1016/j.lcsi.2019.100325.

Christianto, H. (2020). Penggunaan Media Internet Dalam Pemenuhan Hak Atas Pendidikan Di Masa Pandemi Covid-19: Perspektif Hak Asasi Manusia Dan Hukum Pidana. HAM, 11(2), 239-253. 
https://doi.org/10.30641/ham.2020.11.239-253.

Daheri, M., Juliana, J., Deriwanto, D., \& Amda, A. D. (2020). Efektifitas WhatsApp sebagai Media Belajar Daring. Jurnal Basicedu, 4(4), 775-783. https://doi.org/10.31004/basicedu.v4i4.445.

Daheri, Mirzon, Juliana, J., Deriwanto, D., \& Amda, A. D. (2020). Efektifitas WhatsApp sebagai Media Belajar Daring. Jurnal Basicedu, 4(4), 775-783. https://doi.org/10.31004/basicedu.v4i4.445.

Dewi, W. A. F. (2020). Dampak COVID-19 terhadap Implementasi Pembelajaran Daring di Sekolah Dasar. Jurnal Edukatif Ilmu Pendidikan, 2(1). https://doi.org/10.31004/edukatif.v2i1.89.

Dhawan, S. (2020). Online Learning: A Panacea in the Time of COVID-19 Crisis. Journal of Educational Technology Systems, 49(1), 5-22. https://doi.org/10.1177/0047239520934018.

Garad, A., Al-Ansi, A. M., \& Qamari, I. N. (2021). The Role Of E-Learning Infrastructure And Cognitive Competence In Distance Learning Effectiveness During The Covid-19 Pandemic. Cakrawala Pendidikan, 40(1). https: //doi.org/10.21831/cp.v40i1.33474.

Gillett-Swan, J. (2017). The Challenges of Online Learning: Supporting and Engaging the Isolated Learner. Journal of Learning Design, 10(1). https://doi.org/10.5204/jld.v9i3.293.

Hamaidi, D. A., Arauri, Noufal, R. K., \& Aldrou, I. T. (2021). Parents ' Perceptions of Their Children 's Experiences With Distance Learning During the COVID-19 Pandemic. The International Review of Research in Open and Distributed Learning, 22(2). https://doi.org/10.19173/irrodl.v22i2.5154.

Hamid, R., Sentryo, I., \& Hasan, S. (2020). Online learning and its problems in the Covid-19 emergency period. Jurnal Prima Edukasia, 8(1), 86-95. https://doi.org/10.21831/jpe.v8i1.32165.

Handarini, O. I., \& Wulandari, S. S. (2020). Pembelajaran Daring Sebagai Upaya Study From Home (SFH). Jurnal Pendidikan Administrasi Perkantoran (JPAP), 8(3), 465-503.an. Jurnal Pendidikan $\begin{array}{llll}\text { Administrasi } & \text { Perkantoran } & \text { (JPAP), }\end{array}$ https://journal.unesa.ac.id/index.php/jpap/article/view/8503.

Handayani, R., Arif, M., \& Syam, A. (2020). Pembelajaran Daring Pada Anak Usia Sekolah Dasar Masa Pendemi Covid-19 Di Kecamatan Pauh. Kepemimpinan Dan Kepengurusan Sekolah, 5(2), 107-114. https://doi.org/10.34125/kp.v5i2.516.

Hanifah Salsabila, U., Irna Sari, L., Haibati Lathif, K., Puji Lestari, A., \& Ayuning, A. (2020). Peran Teknologi Dalam Pembelajaran Di Masa Pandemi Covid-19. Al-Mutharahah: Jurnal Penelitian Dan Kajian Sosial Keagamaan, 17(2), 188-198. https://doi.org/10.46781/al-mutharahah.v17i2.138.

Hartmann, U., Kindlinger, M., \& Trempler, K. (2021). Integrating information from multiple texts relates to pre-service teachers' epistemic products for reflective teaching practice. Teaching and Teacher Education, 97. https://doi.org/10.1016/j.tate.2020.103205.

Heng, K., \& Sol, K. (2020). Online learning during COVID-19: Key challenges and suggestions to enhance effectiveness. Cambodian Education Forum (CEF). https://doi.org/10.1371/journal.pone.0248758.

Herdiana, D., Rudiana, R., \& Supriatna, S. (2021). Kejenuhan Mahasiswa dalam Mengikuti Perkuliahan Daring dan Strategi Penanggulangannya. Edunesia: Jurnal Ilmiah Pendidikan, 2(1), 293-307. https://doi.org/10.51276/edu.v2i1.128.

Hill, G., Mason, J., \& Dunn, A. (2021). Contract cheating: an increasing challenge for global academic community arising from COVID-19. Research and Practice in Technology Enhanced Learning, 1-20. https://doi.org/10.1186/s41039-021-00166-8.

Hong, J.-C., Lee, Y.-F., \& Ye, J.-H. (2021). Procrastination predicts online self-regulated learning and online learning ineffectiveness during the coronavirus lockdown. Personality and Individual Differences, 174, 110673. https://doi.org/10.1016/j.paid.2021.110673.

Hughes, L. J., Johnston, A. N. B., \& Mitchell, M. L. (2019). How organisational processes influence assessors' experiences of marginal students' performances in clinical assessments. Collegian, 26(2). https://doi.org/10.1016/j.colegn.2018.07.010.

Hung, C.-M., Huang, I., \& Hwang, G.-J. (2014). Effects of digital game-based learning on students' self-efficacy, motivation, anxiety, and achievements in learning mathematics. Journal of Computers in Education, 1(2-3), 151-166. https://doi.org/10.1007/s40692-014-0008-8.

Hutauruk, A., \& Sidabutar, R. (2020). Kendala pembelajaran daring selama masa pandemi di kalangan mahasiswa pendidikan matematika: Kajian kualiatatif deskriptif. Journal of Mathematics Education and Applied, 02(01), 45-51. https://doi.org/10.36655/sepren.v2i1.364.

Indrawati, M., Prihadi, C., \& Siantoro, A. (2020). The Covid-19 Pandemic Impact on Children's Education in Disadvantaged and Rural Area Across Indonesia. International Journal of Education (IJE), 8(4), 1933. https://doi.org/10.5121/ije.2020.8403.

Kao, C.-W. (2020). The effect of a digital game-based learning task on the acquisition of the English Article System. System, 95. https://doi.org/10.1016/j.system.2020.102373.

Kaplan, L. R., Farooque, M., Sarewitz, D., \& Tomblin, D. (2021). Designing Participatory Technology Assessments: A Reflexive Method for Advancing the Public Role in Science Policy Decision-making. 
Technological Forecasting and Social 171. https: //doi.org/10.1016/j.techfore.2021.120974.

Kim, G., \& Gurvitch, R. (2020). Online Education Research Adopting the Community of Inquiry Framework: A Systematic Review. Quest, 72(4), 395-409. https://doi.org/10.1080/00336297.2020.1761843.

Kurniati, E., Nur Alfaeni, D. K., \& Andriani, F. (2020). Analisis Peran Orang Tua dalam Mendampingi Anak di Masa Pandemi Covid-19. Jurnal Obsesi: Jurnal Pendidikan Anak Usia Dini, 5(1), 241. https://doi.org/https://doi.org/10.31004/obsesi.v5i1.541.

Lage-Cala, S., Folgueras-Díaza, M. B., Alonso-Hidalgoa, M., García-Menéndezb, D., \& Fernández-Garcíab, F. J. (2020). Investigation of the effectiveness of online learning tools for energy performance certificates preparation. Energy Reports, 6, 609-614. https://doi.org/10.1016/j.egyr.2019.09.034.

Logan, R. M., Johnson, C. E., \& Worsham, J. W. (2021). Development of an E-learning Module to Facilitate Student Learning and Outcomes. Teaching and Learning in Nursing, 16(2), 139-142. https://doi.org/10.1016/j.teln.2020.10.007.

Malyana, A. (2020). Pelaksanaan Pembelajaran Daring Dan Luring Dengan Metode Bimbingan Berkelanjutan Pada Guru Sekolah Dasar Di Teluk Betung Utara Bandar Lampung. Pedagogia: Jurnal Ilmiah Pendidikan Dasar Indonesia, 2(1), 67-76. https://doi.org/10.52217/pedagogia.v2i1.640.

Mastura, \& Santaria, R. (2020). Dampak Pandemi Covid-19 terhadap Proses Pengajaran bagi Guru dan Siswa. Studi Guru Dan Pembelajaran, 3(2), 289-295. https://doi.org/10.30605/jsgp.3.2.2020.293.

Meşe, E., \& Sevilen, Ç. (2021). Factors influencing EFL students' motivation in online learning: A qualitative case study. Journal of Educational Technology \& Online Learning, 4(1), 11-22. https://doi.org/10.31681/ jetol.817680.

Morze, N., Varchenko-Trotsenko, L., Terletska, T., \& Smyrnova-Trybulska, E. (2021). Implementation of adaptive learning at higher education institutions by means of Moodle LMS. Journal of Physics: Conference Series, 1840(1). https://doi.org/10.1088/1742-6596/1840/1/012062.

Mustakim. (2020). Efektivitas Pembelajaran Daring Menggunakan Media Online Selama Pandemi Covid-19 Pada Mata Pelajaran Matematika the Effectiveness of E-Learning Using Online Media During the Covid-19 Pandemic in Mathematics. Al Asma: Journal of Islamic Education, 2(1), 1-12. https://doi.org/10.24252/asma.v2i1.13646.

Purwanto, A., Pramono, R., Asbari, M., Santoso, P. B., Wijayanti, L. M., Hyung, C. C., \& Setyowati, R. (2020). Studi Eksploratif Dampak Pendemi COVID-19 Terhadap Pembelajaran Online di Sekolah Dasar. Journal of Education, Psychology and Counseling, 2(1), 1-12.

Puspitasari, F. F., Mukti, T. S., Supriyanto, \& Munadi, M. (2021). Character Building Through the Synergy Between Parents and School in Indonesia. Proceedings of the International Conference on Engineering, Technology and Social Science (ICONETOS 2020), 529(Iconetos 2020), 16-21. https://doi.org/10.2991/assehr.k.210421.003.

Putra, R. W. P. (2021). Improving the Students' Motivation in Learning English through Google Meet during the Online Learning. English Learning Innovation, 2(1), 35-42. https://doi.org/10.22219/englie.v2i1.14605.

Putria, H., Maula, L. H., \& Uswatun. D. A. (2020). Analisis Proses Pembelajaran Dalam Jaringan (DARING) Masa Pandemi COVID-19 pada Guru Sekolah Dasar. Jurnal Basicedu, 4(4), 861-872. https://doi.org/10.31004/basicedu.v4i4.460.

Putria, H., Maula, L. H., \& Uswatun, D. A. (2020). Analisis Proses Pembelajaran dalam Jaringan (DARING) Masa Pandemi Covid- 19 Pada Guru Sekolah Dasar. Jurnal Basicedu, 4(4), 861-872. https://doi.org/10.31004/basicedu.v4i4.460.

Rasidi, A. M., Hikmatullah, N., \& Sobry, M. (2021). Hambatan guru dalam pembelajaran daring : Studi kasus di kelas V MIN 2 Kota Mataram. Jurnal Ilmiah Pendidikan Dasar, VIII(2), 159-174. https://doi.org/10.30659/pendas.8.2.159-174.

Realistis, P. K. K. P. M. S. D. dan T. V. K. M. (2020). COVID-19 variant radiological findings with high lightening other coronavirus family (SARS and MERS) findings: radiological impact and findings spectrum of corona virus (COVID-19) with comparison to SARS and MERS. Egyptian Journal of Radiology and Nuclear Medicine, 51(1). https://doi.org/10.1186/s43055-020-00262-7.

Retnawati, H. (2017). Teknik Pengambilan Sampel. September 2017.

Rigianti, H. A. (2020). Kendala Pembelajaran Daring Guru Sekolah Dasar Di Banjarnegara. Elementary School: Jurnal Pendidikan Dan Pembelajaran Ke-SD-An, 7(2). https://doi.org/10.31316/esjurnal.v7i2.768.

Roni Hamdani, A., \& Priatna, A. (2020). Efektifitas Implementasi Pembelajaran Daring (Full Online) Dimasa Pandemi Covid- 19 Pada Jenjang Sekolah Dasar Di Kabupaten Subang. Didaktik: Jurnal Ilmiah PGSD STKIP Subang, 6(1), 1-9. https://doi.org/10.36989/didaktik.v6i1.120.

Rosali, E. S. (2020). Aktifitas Pembelajaran Daring Pada Masa Pandemi Covid-19 di Jurusan Pendidikan 
Geografi Universitas Siliwangi Tasikmalaya. Geography Science Education Journal (GEOSEE), 1(1), 21-30. http://jurnal.unsil.ac.id/index.php/geosee/article/view/1921.

Ryu, K., Kim, Y., \& Woo, M. (2021). False accusation of online games: Internet gaming can enhance the cognitive flexibility of adolescents. Asian Journal of Sport and Exercise Psychology, 1(2). https://doi.org/10.1016/j.ajsep.2021.09.006.

Sadikin, A., \& Hamidah, A. (2020). Pembelajaran Daring di Tengah Wabah Covid-19. Jurnal Ilmiah Pendidikan Biologi, 6(02), 214-224. https://doi.org/10.22437/bio.v6i2.9759.

Saha, A., Dutta, A., \& Sifat, R. I. (2021). The mental impact of digital divide due to COVID-19 pandemic induced emergency online learning at undergraduate level: Evidence from undergraduate students from Dhaka City. Journal of Affective Disorders, 294(1). https://doi.org/10.1016/j.jad.2021.07.045.

Satrianingrum, A. P., \& Prasetyo, I. (2020). Persepsi Guru Dampak Pandemi Covid-19 terhadap Pelaksanaan Pembelajaran Daring di PAUD. Jurnal Obsesi: Jurnal Pendidikan Anak Usia Dini, 5(1), 633. https://doi.org/10.31004/obsesi.v5i1.574.

Silwana, A., Subanji, S., Manyunu, M., \& Rashahan, A. A. (2020). Students' Responses Leveling in Solving Mathematical Problem Based on SOLO Taxonomy Viewed from Multiple Intelligences. Indonesian Journal on Learning and Advanced Education (IJOLAE), 3(1), 1-16. https://doi.org/10.23917/ijolae.v3i1.10528.

Simanjuntak, H., Endaryono, B. toni, \& Balyan. (2020). Bakti Peran Teknologi Informasi dalam Proses Kegiatan Belajar Mengajar di Sekolah Dasar. Inventa, 4(1), 1-10. https://doi.org/10.36456/inventa.4.1.a2122.

Sindiani, A. M., Obeidat, N., Alshdaifat, E., Elsalem, L., Alwani, M. M., Rawashdeh, H., Fares, A. S., Alalawne, T., \& Tawalbeh, L. I. (2020). Distance education during the COVID-19 outbreak: A cross-sectional study among medical students in North of Jordan. Annals of Medicine and Surgery, 59, 186-194. https://doi.org/10.1016/J.AMSU.2020.09.036.

Slovaček, K. A., \& Čosić, G. (2020). The Role of Parents during the COVID19 Pandemic in Croatia. Studies in Educational Management, 8(8), 9-17. https://doi.org/10.32038/sem.2020.08.02.

Soucy, J. N., Owens, V. A. M., Hadjistavropoulos, H. D., Dirkse, D. A., \& Dear, B. F. (2016). Educating patients about Internet-delivered cognitive behaviour therapy: Perceptions among treatment seekers and non-treatment seekers before and after viewing an educational video. Internet Interventions, 6, 5763. https://doi.org/10.1016/j.invent.2016.09.003.

Subandi. (2011). Deskripsi Kualitatif Sebagai Satu Metode Dalam Penelitian Pertunjukan. Harmonia, 11(2), 173-179. https://doi.org/10.15294/harmonia.v11i2.2210.

Sugiyono. (2012). Metode Penelitian Kuantitatif, Kualitatif, dan R\&D. Alfabeta.

Sugiyono. (2015). Metode penelitian pendidikan pendekatan kuantitatif, Kualitatif dan R\&D. Alfabeta.

Summak, M. S., Bağlıbel, M., \& Samancioğlu, M. (2010). Technology readiness of primary school teachers: A case study in Turkey. Procedia - Social and Behavioral Sciences, 2(2), 2671-2675. https://doi.org/10.1016/j.sbspro.2010.03.393.

Susilowati, E., \& Azzasyofia, M. (2020). The parents stress level in facing children study from home in the early of covid-19 pandemic in Indonesia. International Journal of Science and Society, 2(3), 1-12. https://doi.org/10.200609/ijsoc.v2i3.117.

Tan, C. (2021). The impact of COVID-19 on student motivation, community of inquiry and learning performance. Asian Education and Development Studies, 10(2), 308-321. https://doi.org/10.1108/AEDS-05-2020-0084.

Teräs, M., Suoranta, J., Teräs, H., \& Curcher, M. (2020). Post-Covid-19 Education and Education Technology 'Solutionism': a Seller's Market. Postdigital Science and Education, 2(3), 863-878. https://doi.org/10.1007/s42438-020-00164-x.

Thoyyibah, N., Hartono, R., \& Bharati, D. A. L. (2019). The Implementation of Character Education in the English Teaching Learning Using 2013 Curriculum. English Education Journal, 9(2), 254-266. https://doi.org/10.15294/eej.v9i2.30058.

Tiwery, W. Y., Patty, F. N., \& Nanlohy, D. F. (2021). Role Of Family For Children's Education During A Pandemic In Eastern Indonesia. Turkish Journal of Computer and Mathematics Education (TURCOMAT), 12(7), 1522-1527. https://doi.org/10.17762/turcomat.v12i7.2965.

Trisnani. (2017). Pemanfaatan Whatsapp Sebagai Media Komunikasi dan Kepuasan dalam Penyampaian Pesan Dikalangan Tokoh Masyarakat. Komunikasi, Media Dan Informatika, 6(November). https://doi.org/10.31504/komunika.v6i3.1227.

Udayani, N. K. R. T. K., Wibawa, I. M. C., \& Rati, N. W. (2021). Development Of E-Comic Learning Media On The Topic Of The Human Digestive System. Journal of Education Technology, 5(3), 472-481. https://doi.org/10.23887/jet.v5i3.34732.

Usher, M., Hershkovitz, A., \& Forkosh-Baruch, A. (2021). From data to actions: Instructors' decision making 
based on learners' data in online emergency remote teaching. British Journal of Educational Technology, 52(4), 1338-1356. https://doi.org/10.1111/BJET.13108.

Wang, S., Jiao, H., Young, M. J., Brooks, T., \& Olson, J. (2018). Comparability of Computer-Based and Paperand-Pencil Testing in K-12 Reading Assessments: A Meta-Analysis of Testing Mode Effects. Educational and Psychological Measurement, 68(1). https://doi.org/10.1177/0013164407305592.

Weldon, A., Ma, W. W. K., Ho, I. M. K., \& Ma, W. W. K. (2021). Online learning during a global pandemic: Perceived benefits and issues in higher education. Knowledge Management \& E-Learning, 13(2), 161-181. https://doi.org/10.34105/j.kmel.2021.13.009.

Wu, W. H., Kao, H. Y., Wu, S. H., \& Wei, C. W. (2019). Development and evaluation of affective domain using student's feedback in entrepreneurial Massive Open Online Courses. Frontiers in Psychology, 10(MAY). https://doi.org/10.3389/fpsyg.2019.01109.

Wuarlela, M. (2020). Variasi Metode Dan Media Pembelajaran Daring Untuk Mengakomodasi Modalitas Belajar. ARBITRER: Jurnal Pendidikan Bahasa Dan Sastra Indonesia, 2(2), 261-272. https://doi.org/10.30598/arbitrervol2no2hlm261-272.

Xie, J., Wang, M., \& Hooshyar, D. (2021). Student, parent, and teacher perceptions towards digital educational games: How they differ and influence each other. Knowledge Management \& ELearning, 13(2), 142-160. https://doi.org/10.34105/j.kmel.2021.13.008.

Yulia, H. (2020). Online Learning to Prevent the Spread of Pandemic Corona Virus in Indonesia. English Teaching Journal, 11, 48-56. https://doi.org/10.26877/eternal.v11i1.6068.

Yulian, V. N. (2018). Developing Teaching Materials Using Comic Media to Enhance Students' Mathematical Communication. IOP Conference Series: Materials Science and Engineering, 335(1). https://doi.org/10.1088/1757-899X/335/1/012110.

Yuzulia, I. (2021a). The Challenges Of Online Learning During Pandemic : Students ' V oice. Jurnal Bahasa Dan Sastra, 13(1), 8-12. https://doi.org/10.31294/w.v13i1.9759.

Yuzulia, I. (2021b). The Challenges of Online Learning during Pandemic: Students' Voice. Wanastra: Jurnal Bahasa Dan Sastra, 13(1), 08-12. https://doi.org/10.31294/w.v13i1.9759. 